
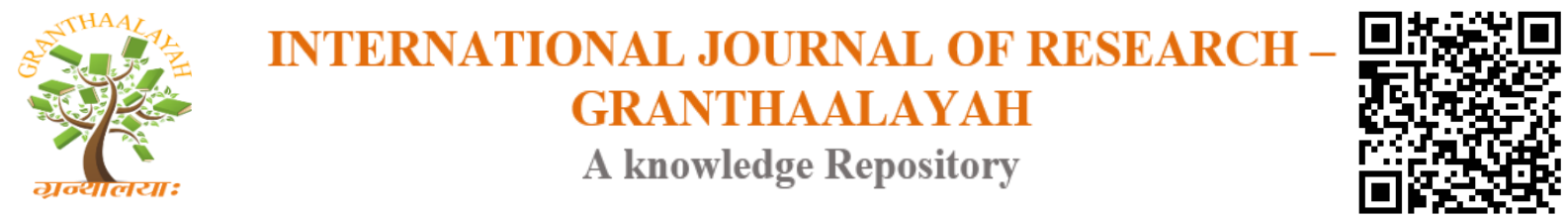

Management

\title{
ANALYSIS OF THE MANAGEMENT OF A BRAZILIAN CONSTRUCTION COMPANY
}

\author{
Flávia Fernandes Fonseca ${ }^{1}$, Ana Carolina Silva Pereira ${ }^{2}$, Ivna do Rosário Olivera ${ }^{3}$, Luiz \\ Augusto de Araujo Duarte Oliveira ${ }^{4}$, Dr. Paulo Lourenço Domingues $\mathrm{Jr}^{5}$ \\ 1, 2,3,4 Federal Rural University of Rio de Janeiro (UFRRJ), campus Three Rivers \\ ${ }^{5}$ Phd in Sociology (USP - Brazil). Professor at Federal Rural University of Rio de Janeiro
}

(UFRRJ), campus Three Rivers

\begin{abstract}
The aim of the study was through a research of a company linked to the construction sector in Brazil; identify the strengths and weaknesses that the organization has. The subjects covered were: the company's goals, addressing how this works in relation to planning; the company management in order to demonstrate how it is performed its management in general and if it is done properly; legislation in which note the importance of compliance with laws within a company linked to the construction sector and finally, people management in which attempts to show how it is done within the organization and what are the improvements so that the company can best achieve the goals. Regarding methodology, directly applying questionnaire was used and interview with the owner of the organization. Thus, through the results and final discussions, it is important to note that many companies, large or small must be willing to always improve and innovate so that it has a differential in the market. Moreover, the importance of a link between all areas is great because through it, the company can improve its performance in a huge percentage.
\end{abstract}

Keywords: Planning; Organization; Strategy; Mission; Construction.

Cite This Article: Flávia Fernandes Fonseca, Ana Carolina Silva Pereira, Ivna do Rosário Olivera, Luiz Augusto de Araujo Duarte Oliveira, and Dr. Paulo Lourenço Domingues Jr. (2018). "ANALYSIS OF THE MANAGEMENT OF A BRAZILIAN CONSTRUCTION COMPANY." International Journal of Research - Granthaalayah, 6(1), 297-305. https://doi.org/10.29121/granthaalayah.v6.i1.2018.1620.

\section{Introduction}

This study, based on results from questionnaires and interviews, aims to develop a reflection on the functioning of a particular company in the interior of Rio de Janeiro, Brazil, explained from its main objectives to carry out personnel management, in order to highlight errors and improvements to be made. 
The research aims to better understand how the work is done within the organizations to find out if what is learned in theory is done so in practice. Thus, try to make a comparison to determine whether the company is following the right path or not.

For a better understanding to the reader, this work was divided into 3 parts. At first, it is the presentation of the studied company and its main objective. In the following section, there is the administration generally performed in the organization. Finally, we identify the strengths and weaknesses of the human resources area within the researched environment.

The aim is to complete the way companies behave in the present times is sufficient to ensure good profits. Thus, attempts to emphasize the importance of a well-organized administration and planned within the organization so that it can reduce losses and achieve their goals.

\section{Corporate Objective}

To born a business, you need planning and strategy. In some cases, account is beyond skill and intelligence, a little luck and future vision for an organization to work out. Starting a business requires a great effort and a great willingness to risk. Thus, the first steps are also very difficult, so we need to be looking for tools that serve to support its activities, such as planning. The businessman said how he built the company Buildings and Mergers LTDA:

"Destiny organized a meeting between me and my partner in mid-2007, since then we started talking about the possibility of creating a construction company, to operate in the public housing market. I had great experience in this industry, and he had the necessary capital. So I looked for a great and suitable land to develop a project after finding and negotiating the possibility of purchase, developed a study of technical and economic feasibility, introduced him to my future partner, which approved and made the purchase of the land. With the experience and help of an architect, developed a project to build an enterprise residential buildings. So we hired an accounting firm, created the Buildings and Real Estate Development LTDA, built a seat, buy the furniture in addition to the machines and tools needed, hire employees, we obtained all necessary licenses, and left to run."

After the interview with the manager and after the completed questionnaire, we arrived at some conclusions about the organization. An important aspect noted during a question drew attention: the mission of the company is set and all who work in know it. The organization studied has its directly traced objective and planned but it is not known to all. In this case, it is necessary that the company manager pass the mission for all employees so that they can achieve better results because each will know exactly which part is and what needs to be done from production to sale. The connection of the areas is of utmost importance to avoid setbacks. Strategic planning should be common knowledge for more positive results in the organization. As a highlight also noted during the survey, it is the fact that the company follow exactly what offers to buyers and thus spends a great confidence to customers. One comes to the conclusion, therefore, that the company has been doing a great job in running field.

A great tip for all companies to achieve goals is that when a year is coming to its end, is the ideal time to stop and conducted a feedback of all that occurred during that time. Time to reflect on 
whether the objectives have been achieved, if the goals were achieved and what should be done to improve the organization. Companies must perform the so-called strategic planning, through the commitment of all staff. The Planning and Action Plan is one of the most important documents of a company, which can be defined as a set of ideas in order to achieve the objectives and contribute to the growth of the organization. ${ }^{1}$

"The well managed you know exactly what is the result, if the result is not positive is necessary to correct the mistakes before it is too late, often the company presents profit, but that does not necessarily mean that the company is good. We need to assess if the investment and the return is in line with expectations. On the other hand, if the company is giving a very favorable return, the possibility of new investments needs to be assessed, the money begets money, but if we do not use it the right way can be a huge headache. " 2

\section{The Company's Management}

The concept of management is represented by the management of a company, organization, institution or governance on something that involves activities, resources and decisions, and that all activities are managed with planning, organization, leadership, execution and control, relating efficient and effective use of all available resources. To experience the act of management, it is essential to have available processes and people (employees), and that these employees work in teams to achieve their goals as well as the company's goals. ${ }^{3}$

According to Maximiano (2004) administration consists of a dynamic process of decision making and implementation of actions, bringing together a connected circuit of activities. Thus, an administrator should through daily decisions and activities to achieve results, with the use of resources and materials available in the company.

\subsection{Main Activities to Manage}

Planning: Through planning is defined business objective, to prepare the goals. This is a vision that occurs with much study and research, to identify strengths, weaknesses, opportunities and future threats. With the planning decisions made by the leaders, we need to pass their goals for the collaborators to work in a team and on behalf of the company and thus achieve the goals. This activity is exercised by the general management of the company.

Organization: It is the preparation of procedures to facilitate the disposition of assets in the company structure, in order to achieve planned objectives.

Leadership: Process that involves working with people for the achievement of group goals. One of the most complex processes, it involves several people management activities and is essential for carrying out all administrative processes. Organizations need a leader in each sector depending on the size of the company, which are titrated with the name of office manager.

Execution: It is a process that involves the action of performing a planned project with the implementation of the strategies through people. 
Control: Compares the achievement of current activities planned initially to restrict and regulate the tasks. Use planning as a measure that should be followed and thus perform a feedback failures and fixes. Always seeks the achievement of business objectives within the required parameters. $^{3}$

They are all steps of an overall process within an organization, which must be carried out in an integrated way for the company to stabilize the market. A company should provide some events to react quickly to the volatility of the economy. This ability to understand the whole system to perform an analysis to identify links to particular facts of a company, it is necessary for the management of organizations. ${ }^{3}$

\subsection{Organizational Functions}

In pursuing the objectives of an organization, it is necessary to use specialized jobs where people are running the company; these tasks are the organizational functions. Each of these functions should be performed with the main activities to manage. The main organizational functions are: production, marketing, research and development, finance and human resources.

Production: Providing products, where the feedstock is converted into another product, and in the case of services, clients are processed and processed. The goal is to provide the company's product or service to the customer.

Marketing: It has the function to maintain the link between the company and its customers, consumers, employees, users and audience. It covers various functions such as: research, product development, distribution, price, promotion and sales.

Research and Development: Transforms marketing information on new products and services. Introduction of technologies and improved production processes.

Finance: It is responsible for function and accountability for the company money. To return to investors over the whole financial part of it is in the company. Also, there are outlets for investment decisions, financing, control and allocation of results.

Human Resources: The main objectives of this function are to find, attract and keep people who are necessary for the company. ${ }^{3}$

All these functions are very important for the organization to remain controlled and for the realization of its main goals. Each type of business has its profile and objectives, and within each there are many variations. But all must use all of these functions to a larger organization, with it, the better employees and investors will have access to information faster which helps in making decision. ${ }^{3}$ 


\subsection{General Concepts - Objectives}

Every company in the initial phase should appreciate the importance of the implementation of specific activity which was created with the specific technical knowledge about the product or service offered. After this initial phase, comes the business consolidation phase in the market. ${ }^{4}$

The consolidation phase organizing the knowledge required for management and resource optimization. At this stage in the business promotes its major base, so as to maintain an orderly growth. The maturation of the company is complete, when the growth phase takes place as planned. ${ }^{4}$

One of the biggest failures of small and medium enterprises is the structural basis of internal management; they must evolve in line with the growth to stay safe. In Brazil this management structure in small and medium enterprises is not valued by the growth, and when organizations maintain growth without this solid foundation, it is likely that the company will go through a phase of work accumulation, failing to support whole structure mounted after continuous growth. ${ }^{4}$

\subsection{Review of the Company's Issues Examined}

According to the interview during the study, the company Buildings and Real Estate Development LTD shows a complete organizational and administrative structure, with analyzes made regularly for better quality control, agility, control and optimization of resources. These analyzes are important to view the company's return to its leading, you obtain greater power of decision-making and holding meetings to keep all the company's focus. But there are some flaws that undermine the company's use to a more solid structure. The company must change its behavior on the transmission of information; this problem is common in small and medium Brazilian companies. The information is very important for the planning of the company; this aspect affects the organization which can result in small problems to the leader, taking his time to be engaged in other activities.

\section{People Management}

The role of Human Resources is becoming more modern and competitive; he advises other sectors providing information for better performance. Always worrying about learning, teamwork, quality and everything so that the results are positive, adding value to customers, employees and investors. The work of the Human Resources begins with the recruitment. Arising a place in the company and requiring the occupation of the function, the human resources contracts a new professional properly trained to perform such a function. Staff recruitment is responsible for hiring the best professional for the company's offer. ${ }^{5}$

After selecting the most suitable candidate for job in question, the admissions office show all the benefits that the company offers, such as food stamps or food and transportation, health insurance, dental and all others who may be offered to company employees. After the recruitment and hiring, comes training, employee of this department needs to carry out the integration of the new employee in the company's staff. For this step, employees need to do 
training with the monitoring and proper supervision by those responsible for the area in question. Constant training and follow-ups are necessary so that the company always has results in each area. After training, we have the compensation of employees; it has the function of controlling the frequency of company employees. This demand incorporates part of the branch management routine, being responsible for making all calculations of salaries, benefits, taxes, among others. They should always be up to date with information about labor laws. The last major task of the human resources area is shutdown, which is considered responsible for taking care of employees who leave the company. Upon the occurrence of a shutdown, the sector has the function to take care of the items defined by law, making the calculation of values, setting the notice of the employee performing a termination term, among other tasks necessary to turn the company correctly and within the law. ${ }^{5}$

The selection of new employees is made by candidate profile analysis through interviews, tests, dynamics and various other procedures to improve the performance of activities in the company. The labor market increasingly requires professionals who are trained and prepared to adapt to all situations. Train is to make a qualified professional to perform a function, preparing the person for a particular type of work. This is a fundamental tool when choosing a candidate for a job opening. Professionals should be trained in accordance with standardized and modern methods of work and conduct, as well as be updated with the latest techniques, trends and market demands. Usually we find companies looking for good professionals and job vacancies waiting for people who can fit the employer's needs.

According to the company Design Health: Medical and Work, located in Brasil, security is the set of measures that are adopted to minimize workplace accidents, occupational diseases, protect the integrity and the employee's ability to work. It has various subjects such as Introduction to Safety and Occupational Health, Prevention and Risk Control in Machinery, Equipment and Facilities, Psychology in Safety Engineering, Communication and Training, the Safety Engineering Applied Management, Environment and Diseases work, Hygiene, Research Methodology, Legislation, Technical Standards, Civil and Criminal Responsibility, Skills, Environmental Protection, Ergonomics and Lighting, Fire Protection and Explosion Hazards and Risk Management. The picture of a company consists of a multidisciplinary team of Work Safety Technician, Occupational Safety Engineer, Occupational Physician and Nurse Labour. These professionals form what we call in Brazil the SESMT - Specialized Safety Engineering and Occupational Medicine.

In addition, the company's employees are the CIPA - Internal Commission for Accident Prevention, which aims to prevent accidents and diseases resulting from work in order to become permanently compatible work with the preservation of life and health promotion worker. Accident at work is when there is injury or functional disorder that may cause death or permanent loss or temporary reduction of capacity for work. Work injury cases are considered as occurs with the employee providing services by order of the company out of work or are traveling on company business. The role of occupational safety is to eliminate unsafe conditions, and unsafe acts can reduce accidents and occupational diseases. The best way to minimize company costs is to invest in the prevention of accidents, since the cost of an accident can bring numerous losses to the company. Whenever any new function is created in the company, 
immediately one must contact the responsible for preparing the PPRA, so that the occupational risks are described.

The PPRA - Program for Environmental Risk Prevention established by the Department of Safety and Health at Work (Ministry of Labor) through the Regulatory Standard NR 9, Decree $3214 / 78$, of Decree 3214/78, define a methodology action to ensure the preservation of the health and integrity of workers from the risks in the workplace. It is considered the risks the physical, chemical and biological agents with agents present in certain concentrations or intensity. The maximum time worker exposure to them is determined by preset limits. Physical agents are: Noise and vibration; abnormal pressure in relation to atmospheric pressure; Extreme temperatures (high and low); ionizing and non-ionizing radiation. The chemicals that come from the handling and processing of raw materials and inputs are: Dust and fumes; Mists and fogs; Gases and vapors. And the biological are from handling, processing and modification of microscopic living things, including: Genes, bacteria, fungi, bacilli, parasites, protozoa, viruses and the like. The program guides the studies to identify risk agents in the working environment and their relationship with the exposure of people by giving proper treatment to prevent, not to cause harm to workers' health. Some of the benefits of the program are: create preventive mentality in workers and entrepreneurs; reduce or eliminate improvisations; promote awareness of the risks and existing agents in the working environment; develop an approach methodology and analysis of the different situations and conditions of the work environment. ${ }^{6}$

The law states that all employers and institutions that admit workers as employees are required to implement the PPRA. In all work activities where there is employment, there is the program's implementation obligation, they are: industry; service providers; hotels; condominiums; drugstores; schools; supermarkets; hospitals; clubs; carriers; magazines; and non-compliance with the requirements of this standard establishes penalties ranging from fines and interdictions. ${ }^{6}$

Jobs that offer personal growth, sense of belonging and sense of achievement to employees generate the most effective rewards as the internal motivation, which is a feature that should happen within each individual. Motivation can't always be achieved by money. Unfortunately, motivation is not found in all people and not always it comes to the type of performance desired. Financial incentives may be universal motivators, representing the most obvious sign of the employee's recovery. Implementing a bonus system increase the profits and encourage employees to better perform their tasks based on parameters related to profit. ${ }^{7}$

It is worth noting also that there are two types of bonus, one is the chance that is not necessarily linked to a measure of performance that can be monitored and quantified, and has to be seen as a possible prize, offered by the owner or administrator. As the name implies, should be casual without defined frequency, otherwise it may be considered part of salary and loses its value as an incentive. The other bonus is structured to require more intensive planning. The payment is conditional on performance and compliance with pre-established goals, and should evaluate something tangible, which can be easily quantified. ${ }^{7}$

Another important aspect is that the bonus should be a tool to raise an average performance to a higher status and keep it that way or a good performance to a great level and not to turn a poor 
performance on average. The manager must decide if the incentives apply individually, in groups or all employees of the companies. ${ }^{7}$

\section{Conclusions}

What we propose through this work was to reflect on how organizations are performing their activities in day to day based on the research done by questionnaire and interview made in the company Construction and Real Estate Development LTDA, located in the interior of Rio de Janeiro, Brazil.

We deal on the various aspects of management within the company, from the simple goals, the requirements for an administration carried out according to the idea of planning, legislation around the construction company remembering that all companies must follow laws to get the job done in a legal manner, and we finalized with the aspects of human resources and it's great importance for the entire business sector.

According to the research conducted at the company Construction and Real Estate Development LTDA, we can identify that the organization in question positively corresponds to all necessary prerequisites for the smooth running and operation of the intended work and exercised with high effectiveness and efficiency, generating profits and good results for the company and employees.

Finally, the work shows clearly each step of a company development and the importance of the owner in this process. It is worth remembering that there are so many positives as negatives aspects when an administrator has its own business and it is extremely important to gain knowledge and always study the market and innovate. Thus, the chance of success is much better.

\section{References}

[1] Meira, Marcos. (2010). "PlANEJAMENTO ESTRATÉGICO”. Disponível em: <http://ogerente.com.br/rede/gestao-empresarial/metas-e-planejamento-para-alcancar objetivos> Acesso em: 13/05/2016.

[2] Fragoso, Sérgio (2011). "QUAL É O PRINCIPAL OBJETIVO DE UMA EMPRESA?". Disponível em: <http://administracaoesucesso.com/2011/02/02/qual-e-o-principal-objetivo-deuma-empresa/> Acesso em: 13/05/2016.

[3] Maximiano, A.C.A (2004) "INTRODUÇÃO À ADMINISTRAÇÃO”, 6 a ed. São Paulo: Atlas.

[4] Alves, Douglas. (2015) "ADMINISTRAÇÃO DE PEQUENAS E MÉDIAS EMPRESAS PARTE 01". Disponível em: http://pmkb.com.br/artigo/administracao-de-pequenas-e-mediasempresas-parte-01/ Acesso em: 06/06/16

[5] Vidal, Jean. (2015) "QUAIS SÃO AS TAREFAS DE UM RECURSOS HUMANOS?" Disponível em: <http://www.sabesim.com.br/quais-sao-as-principais-tarefas-de-um-recursoshumanos/> Acesso em: 03/06/16.

[6] Christianini, Nelson. (2010) "PPRA - PROGRAMA DE PREVENÇÃO DE RISCOS AMBIENTAIS". Disponível em: $<$ http://www.apsbr.com.br/br/pagina/?id=21/ppra.html $>$ Acesso em: 03/06/16.

[7] Pereira de Carvalho, Marcelo. (2000). "PROGRAMAS DE INCENTIVOS A FUNCIONÁRIOS: PRINCÍPIOS FUNDAMENTAIS (PARTE I/II).” Disponível em: 
$<$ http://www.milkpoint.com.br/radar-tecnico/gerenciamento/programas-de-incentivos-afuncionarios-principios-fundamentais-parte-iii-8651n.aspx> Acesso em: 03/06/16.

*Corresponding author.
E-mail addressflaviafernandes.f@ hotmail.com/anacarolina.spereira@ outlook.com/ivna.oliveira@
hotmail.com/augusto_duarte@icloud.com/pldominguesjr@ig.com.br

